This document was prepared in conjunction with work accomplished under Contract No. DE-AC09-96SR18500 with the U. S. Department of Energy.

\title{
DISCLAIMER
}

This report was prepared as an account of work sponsored by an agency of the United States Government. Neither the United States Government nor any agency thereof, nor any of their employees, makes any warranty, express or implied, or assumes any legal liability or responsibility for the accuracy, completeness, or usefulness of any information, apparatus, product or process disclosed, or represents that its use would not infringe privately owned rights. Reference herein to any specific commercial product, process or service by trade name, trademark, manufacturer, or otherwise does not necessarily constitute or imply its endorsement, recommendation, or favoring by the United States Government or any agency thereof. The views and opinions of authors expressed herein do not necessarily state or reflect those of the United States Government or any agency thereof.

This report has been reproduced directly from the best available copy.

Available for sale to the public, in paper, from: U.S. Department of Commerce, National Technical Information Service, 5285 Port Royal Road, Springfield, VA 22161, phone: (800) 553-6847, fax: (703) 605-6900

email: orders@ntis.fedworld.gov

online ordering: http://www.ntis.gov/help/index.asp

Available electronically at http://www.osti.gov/bridge

Available for a processing fee to U.S. Department of Energy and its contractors, in paper, from: U.S. Department of Energy, Office of Scientific and Technical Information, P.O. Box 62, Oak Ridge, TN 37831-0062,

phone: (865)576-8401,

fax: (865)576-5728

email: $\underline{\text { reports@ adonis.osti.gov }}$ 
Key Words:

Supernate Composition

Sample Analysis

Retention: Permanent

Key References:

Technical Task Request: SP-TTR-2004-00004

Task Plan: WSRC-RP-2004-00270

\section{LITERATURE REVIEW OF THE EFFECTS OF TETRAPHENYLBORATE ON SALTSTONE GROUT: BENZENE EVOLUTION AND TCLP PERFORMANCE}

M. S. Hay, SRNL/WPT

Issue Date: November 16, 2004

Waste Processing Technology Section Savannah River National Laboratory Aiken, SC 29808 
This page was intentionally left blank 


\section{TABLE OF CONTENTS}

LIST OF ACRONYMS .................................................................................................................IV

SUMMARY ...................................................................................................................................... V

1.0 INTRODUCTION................................................................................................................. 1

2.0 DESCRIPTION OF PAST STUDIES................................................................................... 2

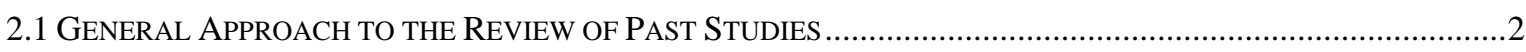

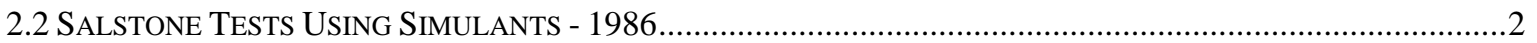

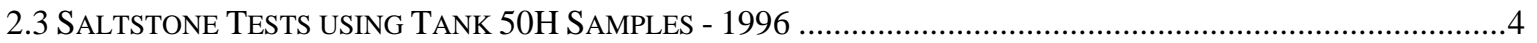

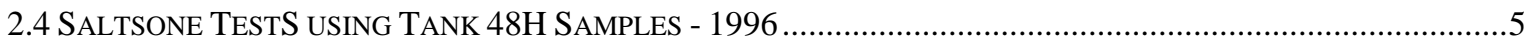

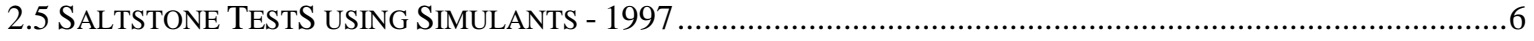

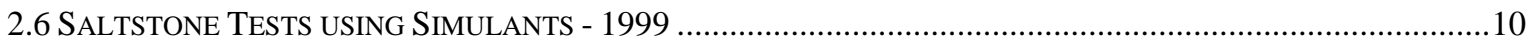

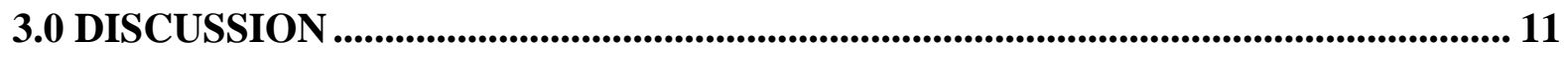

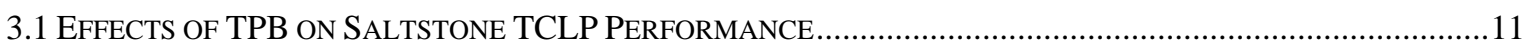

3.2 EFFECTS OF TPB ON BENZENE GENERATION FROM SALTSTONE …....................................................12

4.0 CONCLUSIONS FROM LITERATURE REVIEW ....................................................... 16

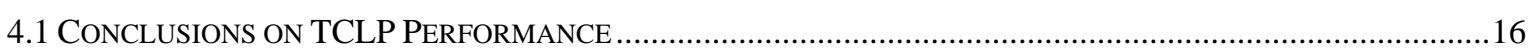

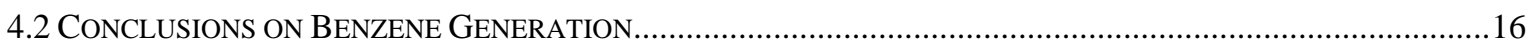

5.0 RECOMMENDATIONS FOR FUTURE TESTING ....................................................... 18

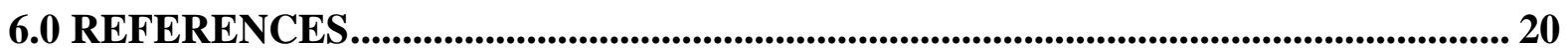




\section{List of Acronyms}

$\begin{array}{ll}\text { TPB } & \text { Tetraphenylborate } \\ \text { TCLP } & \text { Toxicity Characteristic Leaching Procedure } \\ \text { SRS } & \text { Savannah River Site } \\ \text { ITP } & \text { In Tank Precipitation } \\ \text { DWPF } & \text { Defense Waste Processing Facility } \\ \text { SPF } & \text { Saltstone Processing Facility } \\ \text { IR } & \text { Infra-red } \\ \text { GC } & \text { Gas Chromatography } \\ \text { NaTPB } & \text { Sodium Tetraphenylborate } \\ \text { KTPB } & \text { Potassium Tetraphenylborate } \\ \text { GC/MS } & \text { Gas Chromatography-Mass Spectrometry } \\ \text { 3PB } & \text { Triphenylborane } \\ \text { 2PB } & \text { Diphenylborinic Acid } \\ \text { 1PB or PBA } & \text { Phenylboric Acid }\end{array}$


WSRC-TR-2004-00383, REV. 0

\section{SUMMARY}

A review of reports of the past programs investigating the impact of tetraphenylborate (TPB) on saltstone was conducted to support the disposition of the tetraphenylborate in Tank $48 \mathrm{H}$. The review of the literature found the following.

- Toxicity Characteristic Leaching Procedure (TCLP) results show very little benzene leached from saltstone samples prepared from samples containing up to $2000 \mathrm{mg} / \mathrm{L}$ (soluble) TPB with low concentrations of TPB decomposition products. Poorer TCLP performance was observed with saltstone samples prepared from solutions containing elevated concentrations of TPB decomposition products. The concentration of TPB decomposition products that begins to degrade TCLP performance cannot be quantified from the available data.

- $\quad$ The results of past tests suggest the initial form of the TPB in the salt solution (NaTPB or KTPB) does not appear to impact the TCLP performance of saltstone samples. A test conducted to investigate the effects of the saltstone dry blend materials with TPB containing solutions found that NaTPB was quickly removed from solution indicating an interaction with the potassium present in those materials. The TCLP results provide further evidence to suggest that soluble NaTPB in the initial salt solution precipitates or interacts with the potassium in the saltstone dry blend materials effectively producing (insoluble) KTPB in the saltstone.

- $\quad$ The current Tank 48H waste contains $\sim 18,800 \mathrm{mg} / \mathrm{L}$ TPB ( 21,000 mg/L KTPB) with less than detectable concentrations $(<50 \mathrm{mg} / \mathrm{L})$ of TPB decomposition products. The aggregated feed to the Saltstone Processing Facility produced from the Tank $48 \mathrm{H}$ material could have a TPB concentration of up to $5500 \mathrm{mg} / \mathrm{L}$, approximately $2 \mathrm{X}$ higher than any salt solution used for testing to date. The results of the reviewed tests suggest that saltstone prepared from the aggregated feed containing low concentrations of TPB decomposition products should perform well with respect to the TCLP. However, due to the $\sim 2 \mathrm{X}$ higher TPB concentration in the aggregated feed than any salt solution used for testing to date, TCLP testing of saltstone samples prepared using aggregated feed will be needed to verify saltstone prepared from this material will meet regulatory requirements.

- $\quad$ Data from past studies of benzene generation from saltstone samples containing TPB and TPB decomposition products should be used with caution due to the large uncertainty associated with the data. The following conclusions on benzene generation from saltstone samples containing TPB and TPB decomposition products were drawn based on the available data and, therefore, contain the same level of uncertainty.

- The average benzene generation rates, measured over the total duration of a test, span from $<0.1$ to $140 \mu \mathrm{g} / \mathrm{hr}$ per liter of saltstone in the reviewed studies. The peak rates, from individual measurement periods during the tests, range from $<0.1$ to $390 \mu \mathrm{g} / \mathrm{hr}$ per 
liter of saltstone. However, distinguishing what constitutes a statistically significant difference in rate proves difficult due to the high uncertainty present in the data.

- $\quad$ Results of past tests show low benzene generation rates with saltstone samples prepared with salt solutions containing up to $2000 \mathrm{mg} / \mathrm{L}$ TPB with low concentrations of TPB decomposition products. The highest average and peak benzene generation rates were found in saltstone samples prepared from salt solutions containing measurable concentrations of TPB decomposition products. Samples containing only 3PB showed the highest benzene generation rates while samples containing only $2 \mathrm{~PB}$ showed high rates for the first fourteen days and then decreased. These observations concur with the results of the TCLP extractions indicating the probability that decomposition of TPB proceeds at a slow rate in saltstone. The concentration of TPB decomposition products that results in higher benzene generation rates cannot be quantified from the available data.

- $\quad$ Results of past studies suggest the evolution of benzene from saltstone samples may show some temperature dependence with rates increasing with temperature. The change in benzene generation rate as a function of temperature cannot be quantified from the available data. The data also suggests that high peak rates may occur sooner when saltstone samples have been cured at higher temperature.

- $\quad$ Since the current Tank $48 \mathrm{H}$ waste contains less than detectable concentrations $(<50$ $\mathrm{mg} / \mathrm{L}$ ) of TPB decomposition products, the benzene generation rate from saltstone prepared from aggregated Tank $48 \mathrm{H}$ waste might be expected to be quite low based on the available data from past tests. However, given the high uncertainty of the reviewed data from past tests, the possibility of up to an $\sim 2 \mathrm{X}$ higher concentration of TPB in the SPF aggregated feed from Tank $48 \mathrm{H}$ than any salt solution tested to date, and the possibility of higher temperatures for an extended period in the saltstone vault, the benzene generation rate would need to be confirmed with careful experimentation using actual samples from aggregated Tank $48 \mathrm{H}$ waste.

To put the average benzene generation rates found in the review in some perspective, saltstone prepared from Tank $48 \mathrm{H}$ aggregated feed $(5500 \mathrm{mg} / \mathrm{L}$ TPB $)$ would release benzene for $\sim 4000$ years at the rate of $0.1 \mu \mathrm{g} / \mathrm{hr} / \mathrm{L}$ and $\sim 3$ years at the rate of $140 \mu \mathrm{g} / \mathrm{hr} / \mathrm{L}$. These estimates assume complete decomposition of all the TPB present in the saltstone releasing four moles of benzene per mole of TPB. 


\subsection{INTRODUCTION}

As part of the program to disposition the tetraphenylborate (TPB) in Tank 48H and return the tank to service, Salt Processing Development requested a review of the literature to assess the state of knowledge pertaining to incorporation of tetraphenylborate slurries in saltstone grout with respect to benzene generation rates and leaching performance. ${ }^{1,2}$ Examination of past studies conducted at Savannah River Site (SRS) on the incorporation of TPB slurries in saltstone provides a basis for developing a more focused scope of experimental studies.

Tank $48 \mathrm{H}$ currently contains potassium and cesium tetraphenylborate salts as a result of a demonstration of the In Tank Precipitation (ITP) process in 1983 and subsequent ITP radioactive start-up operations in 1995 . The tank currently contains approximately 240,000 gallons of salt solution with approximately $19,000 \mathrm{~kg}(\sim 1.8 \mathrm{wt} \%$ or $\sim 21,000 \mathrm{mg} / \mathrm{L} \mathrm{KTPB})$ of potassium and cesium tetraphenylborate salts. ${ }^{3}$ The presence of the TPB salts makes the waste incompatible with existing High Level Waste treatment facilities. The TPB salts in Tank $48 \mathrm{H}$ must be treated or removed to meet the scheduled return to service date of 2007 .

The two preferred options for disposition of the TBP slurries in Tank $48 \mathrm{H}$ include: ${ }^{4}$

1) Aggregation of the material with the Defense Waste Processing Facility (DWPF) recycle stream and disposal in the Saltstone Processing Facility (SPF), and

2) In-Situ Thermal Decomposition using heat in combination with $\mathrm{pH}$ reduction and catalyst addition.

The current literature review along with the current experimental studies ${ }^{2}$ provide a basis for determining the feasibility of the option to incorporate the TPB slurries into saltstone grout. 
WSRC-TR-2004-00383, REV. 0

\subsection{DESCRIPTION OF PAST STUDIES}

\subsection{GENERAL APPROACH TO THE REVIEW OF PAST STUDIES}

The following contains a description, in chronological order, of past studies conducted at SRS of saltstone samples prepared with solutions containing TPB and/or TPB decomposition products. Although some of the tests described in the following sections may not appear to be directly applicable to the current state of the TPB containing waste in Tank $48 \mathrm{H}$, the results provide insight into the species responsible for benzene release from saltstone samples. Additionally, evidence presented in section 2.5 indicates the high probability that soluble forms of TPB in the salts solutions precipitate or interact with the potassium present in the cement, slag, and flyash materials. Therefore, testing with solutions containing soluble sodium tetraphenylborate (NaTPB) may still be relevant to the current case even though Tank 48H currently contains mostly insoluble potassium tetraphenylborate (KTPB).

In general, the past experiments did not rigorously measure exposed surface areas or attempt to correlate the area to the benzene release rates. Hence, scaling the results to larger volumes of saltstone will have to rely on sample volumes neglecting the potential contribution of exposed surface area. Insufficient data was available to determine the importance of surface area to benzene generation rates. Most of the studies were conducted at room temperature and may not adequately model the higher temperatures expected in a saltstone vault. The few higher temperature experiments indicate that temperature may affect the benzene generation rate from saltstone samples.

Each section begins with a description of the test conditions and conclusions of the study. A more detailed examination of the tests follows with the results of the benzene generation tests and any available TCLP results for benzene. Section 3 provides tables summarizing the experimental results.

\subsection{SALSTONE TESTS USING SIMULANTS - 1986}

In 1986, a study to determine the rate of benzene release from curing saltstone conducted experiments isothermally at two temperatures $\left(25^{\circ} \mathrm{C}\right.$ and $\left.80^{\circ} \mathrm{C}\right)$ and with a temperature profile representing the conditions expected in a curing monolith of saltstone. ${ }^{5}$ The study, concerned only with benzene generated from the decomposition of TPB, used a simulated salt solution spiked with $0.06 \mathrm{wt} \%(\sim 750 \mathrm{mg} / \mathrm{L}) \mathrm{NaTPB}$. The saltstone samples were prepared using $40 \mathrm{wt} \%$ salt solution, $48 \mathrm{wt} \%$ class $\mathrm{C}$ flyash, and $12 \mathrm{wt} \%$ class $\mathrm{H}$ cement. The saltstone samples were placed into a sealed container with sampling ports. Periodically, the vapor space was re-circulated through an in-line infra-red (IR) cell and the benzene quantified. Following the IR measurement the vapor space was purged and trapped for analysis of the benzene evolved by gas chromatography (GC).

The study concluded that the decomposition of TPB to release benzene from saltstone samples was thermally controlled. The highest rates of benzene generation were found during periods of maximum temperature. Additionally, the study concluded that less than $1 \%$ of the 
theoretical maximum benzene was released under the typical temperature profile expected in saltstone monoliths. Although the benzene release rate may depend on the monolith's geometry, the author expected the total benzene release rates to be small. Traces of possibly toluene and xylene were found and thought to be the result of impurities in the NaTPB used in the experiments. The following paragraphs contain more detailed information about the experiments conducted as part of this study.

Very little benzene release was observed in samples cured at $25^{\circ} \mathrm{C}$ with an average rate of $<3 \mu \mathrm{g} / \mathrm{hr}$ per liter of saltstone over the 10 day test as measured by IR. Benzene measurements were made approximately every 24 hours for the duration of the test using the IR method for a total of 11 measurements. GC measurements of the benzene were only made on days 4 through 7 of the test. Most of the measurement made using the IR method found the benzene was less than the detection limits indicating a rate of $<1 \mu \mathrm{g} / \mathrm{hr}$ per liter of saltstone. The four GC data points obtained during the test showed reasonable agreement with the IR results and also indicated a rate of $<1 \mu \mathrm{g} / \mathrm{hr}$ per liter of saltstone. A peak rate of $\sim 9 \mu \mathrm{g} / \mathrm{hr}$ per liter of saltstone was measured in the first 24 hours of the test by IR method. This initial higher rate of benzene generation was not confirmed by GC measurement.

Two other saltstone samples were cured at $80{ }^{\circ} \mathrm{C}$ and showed much higher benzene generation rates than the $25^{\circ} \mathrm{C}$ tests. However, reported problems with steam generation during the $80{ }^{\circ} \mathrm{C}$ tests made the validity of the data questionable. Water vapor has IR bands that can interfere with the $\mathrm{C}-\mathrm{H}$ bands used to measure benzene resulting in a high bias to the measurement. A sample blank was tested at $80{ }^{\circ} \mathrm{C}$ using the same salt solution and dry blend materials but without the addition of NaTPB to the salt solution. The blank showed an average benzene generation rate of $\sim 13 \mu \mathrm{g} / \mathrm{hr}$ per liter of saltstone by IR measurement and $\sim 0.2 \mu \mathrm{g} / \mathrm{hr}$ per liter of saltstone by GC.

For the two $80{ }^{\circ} \mathrm{C}$ test samples, the agreement between the IR and GC results was generally poor with the IR measurements 2-3X higher than GC measurements in the early part of the test. As the tests proceeded, the IR measurements quickly reached the upper quantitation limit so no further comparison could be made. The differences observed between the measurement techniques were attributed to the presence of water vapor not adsorbed by the moisture traps, other organic vapors unresolved by the GC, and inaccuracies in the flow rate measurements. Measurements were made approximately every 24 hours for fourteen days; however, benzene measurements on one of the samples was terminated after 4 days. The data would suggest the samples were still generating high levels of benzene when the tests were terminated. The tests on the saltstone samples cured at $80{ }^{\circ} \mathrm{C}$ produced an average benzene generation rate of approximately 70 to $140 \mu \mathrm{g} / \mathrm{hr}$ per liter of saltstone based on the IR and GC data over the total duration of the tests. The highest peak rate measured in a 24 hour period was $\sim 390 \mu \mathrm{g} / \mathrm{hr}$ per liter of saltstone as determined by GC.

Additionally, for the two saltstone samples used in the $80{ }^{\circ} \mathrm{C}$ tests, two different reaction vessels were employed to provide varying exposed surface area for the two saltstone samples. However, since the samples shrank away from the walls of the vessel, the actual surface areas of the two samples was unknown. 
Two additional saltstone samples were cured using a variable temperature profile chosen to model the temperatures expected in a curing monolith of saltstone. Some modifications were made to the test equipment for these tests including elimination of the IR measurement loop. The released benzene was purged and trapped for measurement by GC on a daily basis. These samples showed the benzene release rate closely followed the temperature profile with rates increasing and decreasing with temperature. The temperature in the tests started at 25 ${ }^{\circ} \mathrm{C}$ and ramped up to $60{ }^{\circ} \mathrm{C}$ by the sixth day. The temperature remained at $60-70{ }^{\circ} \mathrm{C}$ for six days and then gradually dropped back to room temperature at day 30 of the test. One of the samples was $\sim 1 \mathrm{~kg}$ with an exposed surface area of $177 \mathrm{~cm}^{2}$ and the other $\sim 2 \mathrm{~kg}$ with an exposed surface area of $38 \mathrm{~cm}^{2}$. After 55 days the total mass of benzene released from each of the samples was nearly identical and amounted to $<1 \%$ of the theoretical maximum of benzene that would result from the total destruction of TPB present in the saltstone samples. The average rate of benzene release over the 55 days of the test was $\sim 1 \mu \mathrm{g} / \mathrm{hr} / \mathrm{L}(\sim 1.5 \mu \mathrm{g} / \mathrm{hr} / \mathrm{L}$ for the $1 \mathrm{~kg}$ sample and $\sim 0.7 \mu \mathrm{g} / \mathrm{hr} / \mathrm{L}$ for the $2 \mathrm{~kg}$ sample) with peak rates of up to $\sim 5 \mu \mathrm{g} / \mathrm{hr} / \mathrm{L}$ during a 24-hour period when the samples were above $60{ }^{\circ} \mathrm{C}$. The $\mathrm{GC}$ data from the tests appears fairly consistent between day-to-day measurements during periods when the temperature was fairly constant.

The conclusions of the study appear to be based mainly on the results of the variable temperature profile experiment. This indicates the authors recognized the higher uncertainty of the results of the two isothermal tests due to difficulties with the benzene measurements. Notably, no specific rates for benzene generation were mentioned in either the summary or conclusion sections of the report other than stating the rates were expected to be low. The other major conclusion of the study dealt with the possibility that the benzene generation rate may depend on the geometry of the saltstone samples. The study attempted to use varying exposed surface area in the samples to determine the effect on gas generation rates. However, shrinkage of the saltstone samples away from the vessel walls and the high potential for internal cracks makes estimating the exposed surface area of saltstone samples difficult.

\subsection{SALTSTONE TESTS USING TANK 50H SAMPLES - 1996}

A study in 1996 used samples taken from Tank 50H to prepare saltstone samples for determining the effect of TPB on benzene generation and leaching characteristics. ${ }^{6,7,8}$ The saltstone samples were placed in a sealed reaction vessel. A continuous stream of air (20 $\mathrm{mL} / \mathrm{min}$ ) carried any released benzene through a charcoal filter to trap the benzene. Periodically, the charcoal filter was removed and the benzene extracted and measured by gas chromatography-mass spectrometry (GC/MS). The reports contained little characterization data on the Tank $50 \mathrm{H}$ sample, however, the report of leaching tests, with presumably the same sample from Tank $50 \mathrm{H}$, indicates the sample contained $2.3 \mathrm{mg} / \mathrm{L}$ of free benzene and $295 \mathrm{mg} / \mathrm{L}$ tetraphenylborate. ${ }^{9}$ Any TPB present in the Tank $50 \mathrm{H}$ sample was thought to be in the form of the potassium salt (KTPB). The $40 \mathrm{~mL}$ saltstone samples were prepared using 46 wt $\%$ salt solution, $5.4 \mathrm{wt} \%$ cement, $24.3 \mathrm{wt} \%$ flyash, and $24.3 \mathrm{wt} \%$ slag. All the benzene generation tests were conducted at ambient conditions.

The study concluded the benzene generation rate for saltstone made from the Tank $50 \mathrm{H}$ sample ranged from 0.02 to $0.2 \mu \mathrm{g} / \mathrm{hr}$ per liter of saltstone with the maximum rates occurring 
between four and seven days after the start of the test. ${ }^{8}$ The study also concluded that the saltstone samples cured for 14 and 28 days at ambient temperature passed the TCLP test. Samples cured at $60^{\circ} \mathrm{C}$ also passed the TCLP test. ${ }^{9}$

The benzene evolution tests on the Tank $50 \mathrm{H}$ saltstone samples were run at ambient temperature for 55 days with benzene measurements made approximately every four days. The benzene evolution rates over those four-day measurement periods ranged from 0.02 to $0.2 \mu \mathrm{g} / \mathrm{hr}$ per liter of saltstone. However, most of the benzene analytical data obtained in the tests was near or below the detection limit of the analytical method. Replicate samples typically showed differences of $2 \mathrm{X}$ up to $8 \mathrm{X}$. The author attributed the scatter in the data to difficulties with extracting the benzene from the charcoal traps and the small amount of benzene evolved during the test. Additionally, no blanks, controls, or calibration data for the purge and trap method were reported to provide evidence on the reliability of the method to measure the benzene produced in the tests. The average benzene generation rate over the 55 day duration of the test was 0.08 to $0.1 \mu \mathrm{g} / \mathrm{hr}$ per liter of saltstone.

TCLP tests were also conducted on saltstone samples prepared from the same January 1996 Tank $50 \mathrm{H}$ sample. ${ }^{9}$ For the leaching tests, samples of saltstone were frozen in liquid nitrogen, immediately crushed, and transferred to a zero headspace extractor. TCLP results found that all saltstone samples passed the regulatory requirements. The 28 day TCLP result found 1.0 $\mu \mathrm{g} / \mathrm{L}$ benzene versus a regulatory limit of $500 \mu \mathrm{g} / \mathrm{L}$. Additionally, saltstone samples prepared from Tank $50 \mathrm{H}$ salt solution and cured at $60{ }^{\circ} \mathrm{C}$ also passed all regulatory requirements of the TCLP. The 28 day TCLP result for the samples cured at $60{ }^{\circ} \mathrm{C}$ found $4.7 \mu \mathrm{g} / \mathrm{L}$ benzene versus a regulatory limit of $500 \mu \mathrm{g} / \mathrm{L}$.

The conclusions of the study merely stated the results of the experiments and did not provide any general conclusions relating to TPB in saltstone. The discussion in Section 3.0 incorporates the results of this study.

\subsection{SALTSONE TESTS USING TANK 48H SAMPLES - 1996}

Further testing in 1996 used material from Tank $48 \mathrm{H}$ to prepare saltstone samples. ${ }^{10,11,12}$ The Tank $48 \mathrm{H}$ sample was saturated with sodium tetraphenylborate, passed through a cross-flow filter to remove precipitated TPB salts, and then sparged with air to remove free benzene prior to preparing the saltstone samples. The TPB concentration in the Tank $48 \mathrm{H}$ salt solution used in preparing the saltstone samples was approximately $0.15 \mathrm{wt} \%$ ( 2000 $\mathrm{mg} / \mathrm{L})$, presumably of soluble NaTPB. The free benzene in the treated Tank $48 \mathrm{H}$ material was found to be $20-40 \mathrm{mg} / \mathrm{L}$. As in the previous study using Tank $50 \mathrm{H}$ material, the $40 \mathrm{~mL}$ saltstone samples were prepared using $46 \mathrm{wt} \%$ salt solution, $5.4 \mathrm{wt} \%$ cement, $24.3 \mathrm{wt} \%$ flyash, and $24.3 \mathrm{wt} \%$ slag. The same experimental set-up described in section 2.3 was used with Tank $48 \mathrm{H}$ tests employing a constant airflow through the sample container to a charcoal trap.

The study concluded that the benzene evolution rate from saltstone samples prepared from Tank $48 \mathrm{H}$ filtrate ranged from 0.1 to $28.0 \mu \mathrm{g} / \mathrm{hr}$ per liter of saltstone with an average benzene generation rate of $17 \mu \mathrm{g} / \mathrm{hr}$ per liter of saltstone over the course of the 182 day experiment. ${ }^{12}$ The author noted that these rates were approximately $10 \mathrm{X}$ higher than the rates measured in 
the 1986 tests (see Section 2.2). The higher rates were thought to result from the continuous air purge used in the experiment and the higher concentration of TPB in the initial salt solution. The higher rates were also attributed to the free benzene concentration (20-40 $\mathrm{mg} / \mathrm{L})$ in the salt solution, the high soluble TPB concentration, the use of $6 \mathrm{wt} \%$ more salt solution in the saltstone formulation, and effects of irradiation.

Additionally, the study concluded that only $12 \%$ of the benzene evolved from the saltstone samples resulted from the release of the free benzene present in the initial salt solution with the remainder due to the decomposition of TPB and TPB decomposition products. The total benzene released in the test amounted to $10 \%$ of the theoretical yield from the destruction of all the TPB. At the benzene generation rate found in the study $(17 \mu \mathrm{g} / \mathrm{hr}$ per liter of saltstone), the SPF could process 500,000 gal of ITP filtrate without exceeding the 1000 $\mathrm{lb} /$ year benzene release limit. The following paragraphs provide more detail of the experiments.

The tests were continued for 182 days at ambient temperature with samples collected for measurement of the benzene evolved every seven days for the first twenty-eight days of the test and then every 2 weeks for the remainder of the test duration. For the seven-day measurement periods, the benzene evolution rate ranged from 0.16 to $19 \mu \mathrm{g} / \mathrm{hr}$ per liter of saltstone. For the 2-week measurement periods the average benzene evolution rate ranged from 9 to $28 \mu \mathrm{g} / \mathrm{hr}$ per liter of saltstone. The average benzene generation rate for the 182-day duration of the tests was $\sim 17 \mu \mathrm{g} / \mathrm{hr}$ per liter of saltstone. All of the benzene measurements were well above the detection limit, however, duplicate sample measurements made during the first 28 days of the test show differences of up to $60 \mathrm{X}$.

After curing for 7 days, a saltstone sample prepared from the Tank $48 \mathrm{H}$ solution was frozen in liquid nitrogen, immediately crushed, and transferred to a zero headspace extractor. The TCLP results from the 7-day sample found the extract contained $18 \mu \mathrm{g} / \mathrm{L}$ benzene, well under the $500 \mu \mathrm{g} / \mathrm{L}$ regulatory limit. The TCLP extracts from the 28 -day cured saltstone sample showed $27 \mu \mathrm{g} / \mathrm{L}$ benzene.

The conclusions of the study stated the results of the experiments and postulated the cause for the higher rates found in these experiments relative to earlier experiments in 1986. All of reasons offered may have contributed to the higher rates in this experiment. Further experimentation would be needed to quantify all of these contributions. However, the author does quantify the maximum contribution from the free benzene present in the salt solution. The free benzene only accounts for a maximum of $12 \%$ of the benzene generated over the course of the experiment.

\subsection{SALTSTONE TESTS USING SIMULANTS - 1997}

In 1997, tests were conducted with a simple salt solution simulant spiked with various amounts of NaTPB and its decomposition products; triphenylborane (3PB), diphenylborinic acid (2PB), and phenylboric acid (PBA or 1PB). ${ }^{13,14,15,16}$ Saltstone samples prepared from these simple simulant solutions were analyzed by TCLP and the benzene evolution rates measured over a period of 328 days. 
The study concluded that benzene generation rates were highest in samples prepared from solutions containing only $3 \mathrm{~PB}$ releasing $16-31 \%$ of the theoretical maximum over the course of the 328 day experiment. Benzene evolution rates from samples prepared from solutions containing only $2 \mathrm{~PB}$ were high for the first 14 days and then decreased releasing $5-10 \%$ of the theoretical maximum over 328 days. For those samples prepared from solutions containing only TPB or 1PB, the benzene generation rates were very low. For samples containing only $3 \mathrm{~PB}$, the benzene generation rate decreased with increasing $3 \mathrm{~PB}$ concentrations. The author postulated that the $3 \mathrm{~PB}$ may act as a set retarder leading to smaller pore size and decreased transport of the benzene to the surface of the saltstone. Alternatively, the small concentration of TPB "impurity" present in the salt solution may precipitate as KTPB plugging the pores or absorbing benzene. Based on the results of the 12 tests with simple salt solution simulants, the author provided an equation to adjust the experimentally determined benzene generation rates to ITP flowsheet compositions. Another equation was provided to estimate the total benzene generation from a saltstone sample based on the individual contributions of TPB, 3PB, 2PB, and $1 \mathrm{~PB}$ to the overall rate. No further testing in support of the ITP process was recommended at the completion of the study.

A total of 12 different simple salt solutions simulants composed of $\mathrm{NaOH}, \mathrm{NaNO}_{3}$, and $\mathrm{NaNO}_{2}$ with varying compositions of TPB and TPB decomposition products were used to prepare saltstone samples. The benzene generation rates were measured every seven days for the first 28 days of the test period. Measurements were made approximately every 2-weeks from day 28 through day 105, followed by increasingly longer periods between measurements for the remaining duration of the tests. All the tests were conducted under ambient conditions.

Of the twelve salt solutions used in the testing, four of those contained only NaTPB with less than detectable amounts of any TPB decomposition products. The benzene generation rates from the saltstone samples prepared from these four salt solutions were very low. The highest rate measured for these samples was found in the first 7-day period showing $0.3 \mu \mathrm{g} / \mathrm{hr}$ per liter of saltstone. Nearly all of the benzene measurements throughout the test duration for these samples were below detection limits indicating a rate of $<0.15 \mu \mathrm{g} / \mathrm{hr}$ per liter of saltstone.

The highest benzene evolution rates were obtained from saltstone samples prepared from salt solutions containing high concentrations of $3 \mathrm{~PB}$ and/or $2 \mathrm{~PB}$. For these solutions the benzene generation rate reached $270 \mu \mathrm{g} / \mathrm{hr}$ per liter of saltstone during the 2 -week measurement period beginning at day 71 from the start of the test. The rates for many of these samples containing 3PB remained very high for the entire duration of the test.

Additionally, tests were conducted to investigate the effects of the saltstone dry blend materials with TPB containing solutions. A small portion of each dry blend material; cement, slag, or flyash, was added to a portion of salt solution so that free liquid remained above the settled saltstone materials after mixing. The salt solution contained TPB and all of the decomposition products at fairly high concentrations. The free liquid was sampled and analyzed after one day and seven days. The results showed essentially all of the TPB in the 
initial salt solution was no longer present after one day in tests with all three of the dry blend materials. The absence of a commensurate increase in the concentrations of the TPB decomposition products indicates the TPB was removed from solution by the saltstone dry blend materials and not decomposed to 3PB, 2PB, 1PB or phenol. All three of the saltstone dry blend materials, cement, slag and flyash contain potassium. ${ }^{17,}{ }^{18}$ The evidence indicates that the potassium in the dry blend materials precipitates or interacts with the soluble TPB in the salt solution. The flyash and slag were found to affect the concentrations of $3 \mathrm{~PB}$ and $2 \mathrm{~PB}$ in solution. When the salt solution was mixed with the flyash or slag the concentrations of the 3PB (flyash only) and 2PB were significantly decreased while the 1PB concentration increased slightly. This would indicate that something in the flyash and slag increases the decomposition of 3PB (flyash only) and 2PB into $1 \mathrm{~PB}$. This decomposition of the 3PB and $2 \mathrm{~PB}$ was not observed when the salt solution was mixed with the cement.

Saltstone samples prepared from two of the solutions were subjected the TCLP test. The saltstone samples were frozen in liquid nitrogen, immediately crushed, and transferred to a zero headspace extractor. The first solution containing $515 \mathrm{mg} / \mathrm{L} \mathrm{TPB}, 1591 \mathrm{mg} / \mathrm{L} \mathrm{3PB}, 787$ $\mathrm{mg} / \mathrm{L} \mathrm{2PB}$, and $204 \mathrm{mg} / \mathrm{L}$ PBA passed the TCLP requirements with a benzene concentration in the extract of $360 \mu \mathrm{g} / \mathrm{L}$ versus the regulatory limit of $500 \mu \mathrm{g} / \mathrm{L}$. The second solution containing $988 \mathrm{mg} / \mathrm{L} \mathrm{TPB}, 2944 \mathrm{mg} / \mathrm{L}$ 3PB, $2044 \mathrm{mg} / \mathrm{L} \mathrm{2PB}$, and $423 \mathrm{mg} / \mathrm{L}$ PBA failed the TCLP requirements with a benzene concentration in the extract of $960 \mu \mathrm{g} / \mathrm{L}$. The benzene extracted in the TCLP was thought to result from the decomposition of 3PB and $2 \mathrm{~PB}$ based on the fact that the benzene generation tests showed that saltstone samples prepared from salt solutions containing only TPB did not release significant amounts of benzene.

The results of the experiments seem to support the conclusion that higher benzene generation rates occur in saltstone samples prepared with salt solutions containing $3 \mathrm{~PB}$ and $2 \mathrm{~PB}$. The four tests with only TPB showed very low rates. The conclusion that benzene generation rate decreases with increasing $3 \mathrm{~PB}$ concentration was the result of two tests in which one of the salt solutions had twice the concentration of 3PB than the other. However, the 3PB reagent contained TPB, 2PB, 1PB, phenol, and biphenyl impurities at significant concentrations. The presence of these impurities complicates the interpretation of the results. One other important result of the study was that the tests with the saltstone dry blend chemicals indicate that soluble TPB anion was rapidly removed from solution when contacted with cement, slag, or flyash. This indicates that the potassium in the dry blend materials precipitates or interacts with the soluble TPB in the salt solution.

The author provided the equation shown below, to adjust the experimentally determined benzene generation rates to the ITP flowsheet compositions. The equation uses a simple ratio of the ITP flowsheet TPB concentration to the test sample TPB concentration to make the adjustment. The equation assumes a linear relationship between TPB concentration and benzene generation rate, however, no evidence was presented to show a linear relationship exists. Additionally, the equation has not been validated with actual waste.

$\mathrm{R}_{\text {avg }}(\mu \mathrm{g} / \mathrm{L} / \mathrm{hr})=\left[\mathrm{E}_{\text {benzene }}(\mu \mathrm{g}) \bullet \mathrm{C}_{\text {flowsheet }}(\mathrm{M})\right] /\left[\mathrm{C}_{\text {sample }}(\mathrm{M}) \bullet \mathrm{V}(\mathrm{L}) \bullet \mathrm{t}(\mathrm{hr})\right]$ 
The other equation provides for calculating the total benzene generation (mass) from a saltstone sample based on the concentration of TPB, 3PB, 2PB, and 1PB in the salt solution. This equation could potentially be used to estimate a "ballpark" benzene generation for the current case, however, the equations have not been validated with actual waste. The test conditions used to derive these equations were much different than those expected for the current Tank $48 \mathrm{H}$ aggregation option. The individual rates for each of the phenylborates used in calculating the total benzene generation rate were obtained using a very simple salt solution simulant containing only $\mathrm{NaOH}, \mathrm{NaNO}_{3}$, and $\mathrm{NaNO}_{2}$ with no sludge solids or other potential catalyst containing species present. Additionally, all of the experiments were conducted at $25^{\circ} \mathrm{C}$ and the equations assume all decomposition occurs in one year. The equation multiplies the concentration of each phenylborate in the salt solution by a benzene yield determined from the 12 tests. The $\mathrm{X}$ in the bottom line of the equation should be replaced with the volume of TPB containing salt solution processed to make the saltstone sample.

Total Benzene $=[($ TPB conc. $\mathrm{g} / \mathrm{L})(0.001 \mathrm{~g}$ benzene $/ \mathrm{g}$ TPB $)+$ (3PB conc. $\mathrm{g} / \mathrm{L})(0.394 \mathrm{~g}$ benzene/g $3 \mathrm{~PB})+$ (2PB conc. $\mathrm{g} / \mathrm{L})(0.091 \mathrm{~g}$ benzene/g $2 \mathrm{~PB})+$ (1PB conc. $\mathrm{g} / \mathrm{L})(0.006 \mathrm{~g}$ benzene/g $1 \mathrm{~PB})] \bullet$ $[(3.79 \mathrm{~L} / \mathrm{gal}) \bullet(\mathrm{X}$ gal filtrate/yr $) \bullet(1 \mathrm{lb} / 454 \mathrm{~g})]$

Although no further testing was recommended in the report, an additional study was conducted in 1999 (see Section 2.6). 


\subsection{SALTSTONE TESTS USING SIMULANTS - 1999}

In 1999, samples of saltstone were prepared using simple simulant solutions containing 318 $\mathrm{mg} / \mathrm{L}$ of $3 \mathrm{~PB}$ and $20 \mathrm{mg} / \mathrm{L}$ of $2 \mathrm{~PB} .{ }^{19,20}$ The simulant solutions were targeted to also contain $766 \mathrm{mg} / \mathrm{L}$ TPB and $11 \mathrm{mg} / \mathrm{L}$ of $1 \mathrm{~PB}$. However, analysis showed only 3PB and 2PB present in the solutions. The absence of NaTPB and 1PB was not deemed critical to the test since previous results had shown the compounds contributed very little to benzene generation rate. The study used the simple salt solution simulant containing $\mathrm{NaOH}, \mathrm{NaNO}_{3}$, and $\mathrm{NaNO}_{2}$ spiked with $3 \mathrm{~PB}$ and $2 \mathrm{~PB}$ to prepare the saltstone samples. One sample was allowed to cure at ambient temperature while the other was heated to $85^{\circ} \mathrm{C}$ for two days and then allowed to cool. The $85^{\circ} \mathrm{C}$ temperature was thought to represents the maximum temperature expected in a saltstone vault. Again, the same methodology of trapping the benzene in a charcoal trap from a constant airflow through the sample container was used in the tests.

The study found that a saltstone sample heated to $85^{\circ} \mathrm{C}$ for two days produced an average benzene generation rate of $16 \mu \mathrm{g} / \mathrm{hr}$ per liter of saltstone over the 138 day duration of the test with a peak rate of $60 \mu \mathrm{g} / \mathrm{hr}$ per liter of saltstone measured in the first seven days. The total benzene released was $27 \%$ of the theoretical maximum. A saltstone sample cured at ambient temperature produced an average benzene generation rate of $10 \mu \mathrm{g} / \mathrm{hr}$ per liter of saltstone over the 138 day duration of the test with a peak rate of $17 \mu \mathrm{g} / \mathrm{hr}$ per liter of saltstone measured at day 70 in the test. The total benzene released from the sample cured at ambient temperature was $18 \%$ of the theoretical maximum. The authors concluded that heating a saltstone sample to $85^{\circ} \mathrm{C}$ for a few days does not increase the total amount of benzene released significantly, but does cause the peak release rate to occur sooner. No further saltstone testing in support of the ITP process was recommended at the completion of the study.

Both samples were subjected to the TCLP test after a 28-day curing time and easily met the regulatory requirements for benzene. The saltstone samples were frozen in liquid nitrogen, immediately crushed, and transferred to a zero headspace extractor. The sample cured at ambient temperature showed a benzene concentration of $9.5 \mu \mathrm{g} / \mathrm{L}$ in the TCLP extract versus the regulatory limit of $500 \mu \mathrm{g} / \mathrm{L}$. The benzene concentration in the TCLP extract of the sample cured at $85^{\circ} \mathrm{C}$ was $55 \mu \mathrm{g} / \mathrm{L}$.

The conclusions of the study merely stated the results of the experiments. The one more general conclusion, that heating the sample caused the peak benzene generation rate to occur sooner, seems reasonable in light of the test results. However, it should be noted that the saltstone samples were prepared from a very simple salt solution simulant and contained only $3 \mathrm{~PB}$ and $2 \mathrm{~PB}$. The discussion in Section 3.0 incorporates the results of this study. 
WSRC-TR-2004-00383, REV. 0

\subsection{DISCUSSION}

\subsection{EFFECTS OF TPB ON SALTSTONE TCLP PERFORMANCE}

Table 3.1 summarizes the results of the TCLP tests for saltstone samples prepared from salt solutions containing TPB and TPB decomposition products. The saltstone samples prepared from Tank $50 \mathrm{H}$ and Tank $48 \mathrm{H}$ samples performed well in the TCLP test showing very little extractable benzene. The other four entries in the table were prepared from simulants. The two saltstone samples prepared from simulants showing the highest concentrations of benzene in the TCLP extracts (Tests No. 4 and 5) had concentrations of TPB within the range found in the Tank $50 \mathrm{H}$ and Tank $48 \mathrm{H}$ salt solutions. However, these two simulated salt solutions also had high concentrations of TPB decomposition products. Data on the concentrations of TPB decomposition products was not available for the Tank $50 \mathrm{H}$ and Tank $48 \mathrm{H}$ samples. However, given that the Tank $50 \mathrm{H}$ sample contained KTPB, and the Tank $48 \mathrm{H}$ material was a freshly prepared NaTPB solution, the concentration of TPB decomposition products was probably quite low. The poorer TCLP performance of the saltstone samples prepared from the simulant solutions in Test No. 4 and 5 probably results from the presence of the TPB decomposition products since the TPB concentrations were in the same range as the actual waste samples. However, the poorer TCLP performance of Tests No. 4 and 5 may be an artifact of using simulated salt solutions versus actual waste samples.

In any case, the results show very little benzene leached from saltstone samples prepared from tank samples containing TPB with low concentrations of TPB decomposition products. Additionally, the initial form of the TPB in the salt solution does not appear to impact the TCLP performance. The samples prepared from Tank $50 \mathrm{H}$ salt solution, containing primarily KTPB, and those prepared from Tank $48 \mathrm{H}$ salt solution, containing NaTPB, both show low leaching results for benzene. This provides further evidence to suggest that soluble NaTPB in the initial salt solution precipitates or interacts with the potassium in the saltstone dry blend materials.

Tank $48 \mathrm{H}$ currently contains $18,800 \mathrm{mg} / \mathrm{L}$ TPB ( 21,000 mg/L KTPB), with $\sim 99.9 \%$ present as KTPB, and less than detectable concentrations $(<50 \mathrm{mg} / \mathrm{L})$ of $3 \mathrm{~PB}, 2 \mathrm{~PB}$, and $1 \mathrm{~PB} .^{21} \mathrm{The}$ Tank $48 \mathrm{H}$ material will be aggregated with non-TPB containing waste streams in Tank $50 \mathrm{H}$ prior to transfer to the Saltstone Processing Facility reducing the TPB concentration to approximately $5500 \mathrm{mg} / \mathrm{L}$ or less. The results from Table 3.1 suggest that saltstone samples prepared from the Tank $48 \mathrm{H}$ solution containing TPB with minimal concentrations of decomposition products should perform well with respect to the TCLP. However, the TPB concentration expected in the aggregated Tank $48 \mathrm{H}$ waste as feed to the SPF will contain approximately $2 \mathrm{X}$ the highest concentration tested as shown in Table 3.1. Therefore, TCLP testing using waste samples from the aggregated Tank $48 \mathrm{H}$ material will be needed to verify saltstone prepared from this material will meet regulatory requirements. 
Table 3.1. Summary of TCLP results for Saltstone Samples Prepared from Solutions Containing TPB and TPB Decomposition Products

\begin{tabular}{|l|l|c|c|c|c|c|c|c|c|}
\hline $\begin{array}{l}\text { Test } \\
\text { No. }\end{array}$ & $\begin{array}{l}\text { Salt } \\
\text { Solution }\end{array}$ & $\begin{array}{c}\text { Section } \\
\text { in } \\
\text { report }\end{array}$ & $\begin{array}{c}\text { Curing } \\
\text { Temp. } \\
{ }^{\circ} \mathrm{C}\end{array}$ & $\begin{array}{c}\text { TPB } \\
\text { Conc. } \\
(\mathrm{mg} / \mathrm{L})\end{array}$ & $\begin{array}{c}3 \mathrm{~PB} \\
\text { Conc. } \\
(\mathrm{mg} / \mathrm{L})\end{array}$ & $\begin{array}{c}2 \mathrm{~PB} \\
\text { Conc. } \\
(\mathrm{mg} / \mathrm{L})\end{array}$ & $\begin{array}{c}\text { 1PB } \\
\text { Conc. } \\
(\mathrm{mg} / \mathrm{L})\end{array}$ & $\begin{array}{c}\text { Benzene } \\
\text { in TCLP } \\
\text { Extract } \\
(\mu \mathrm{g} / \mathrm{L})\end{array}$ & $\begin{array}{c}\text { Reg. } \\
\text { Limit } \\
(\mu \mathrm{g} / \mathrm{L})\end{array}$ \\
\hline 1 & Tank $50 \mathrm{H}$ & 2.3 & 25 & 295 & NA & NA & NA & 1.0 & 500 \\
\hline 2 & Tank 50H & 2.3 & 60 & 295 & NA & NA & NA & 4.7 & 500 \\
\hline 3 & Tank 48H & 2.4 & 25 & $\sim 2000$ & NA & NA & NA & 27 & 500 \\
\hline 5 & Simulant & 2.5 & 25 & 515 & 1591 & 787 & 204 & 360 & 500 \\
\hline 6 & Simulant & 2.5 & 25 & 988 & 2944 & 2044 & 423 & 960 & 500 \\
\hline 7 & Simulant & 2.6 & 25 & $<10$ & 318 & 20 & $<10$ & 9.5 & 500 \\
\hline
\end{tabular}

Note: TPB, 3PB, 2PB, and $1 \mathrm{~PB}$ concentrations represent the concentrations present in the salt solution used to prepare the saltstone samples. NA - data not available

\subsection{EFFECTS OF TPB ON BENZENE GENERATION FROM SALTSTONE}

The results of the benzene generation studies prove more difficult to assess since most of the testing appears to be scouting in nature. In most of the reports, insufficient data was reported to ascertain the quality of the data. Only two studies used replicate tests that allowed some measure of the uncertainty and indicated large uncertainty in the benzene measurements. A blank or control test using a saltstone sample without TPB was included in only one other study and indicated a fairly high background benzene generation rate presumably from benzene contamination in the simulated salt solution or air supply. The same study was the only one to provide any calibration data for measurement of benzene in the test apparatus but only for the in-line IR measurement loop. None of the studies indicated measurements of the efficiency of the traps to collect benzene were conducted or how well the benzene was desorbed from the trap for measurement by GC. In some of the studies a large percentage of the benzene measurements appear to be near or below the detection limits of the analytical method and shows high amounts of scatter. Several of the reports indicate that difficulties were encountered with the experimental setup and benzene measurements. These points all indicate the results of past studies of benzene generation from saltstone samples containing TPB and TPB decomposition products should be used with caution due to the large uncertainty associated with the data.

Table 3.2 summarizes the results of all the saltstone benzene generation tests reviewed for this report. Of the 19 test results in the table only one used KTPB as the source of TPB in the salts solution used to prepare the saltstone samples. However, as discussed in Section 2.5 and supported by the TCLP results in Section 3.1, test results indicate that NaTPB or soluble TPB 
in the salt solution precipitates or interacts with the potassium in the saltstone dry blend materials. That being the case, the initial form of the TPB in the salt solution would be expected to have little impact on the results of the benzene generation tests. However, that assertion requires further verification. The average benzene generation rates, measured over the total duration of a test, span from $<0.1$ to $140 \mu \mathrm{g} / \mathrm{hr}$ per liter of saltstone. The peak rates, from individual measurement periods during the tests, range from $<0.1$ to $350 \mu \mathrm{g} / \mathrm{hr}$ per liter of saltstone. However, given the high uncertainty present in the data, distinguishing what constitutes a statistically significant change in rate proves difficult.

With the exception of Test No. 2, the results of Tests No. 1 through 9 in Table 3.2 indicate a low benzene generation rate with saltstone samples prepared with salt solutions containing only TPB and low concentrations of TPB decomposition products. This observation was also made from the results of the TCLP extractions indicating the probability that decomposition of TPB proceeds at a slow rate in saltstone. As discussed in Section 2.2, the results of Test No. 2 conducted at $80^{\circ} \mathrm{C}$ appear unreliable due to difficulties encountered with benzene measurements. Test No. 5 prepared with Tank $48 \mathrm{H}$ material shows slightly higher rates compared to the rates in Test No. 1, 3, 4, 6, 7, 8, and 9. However, the difference between these rates cannot be validated given that replicates in the tests with the Tank $48 \mathrm{H}$ samples showed differences as high as $60 \mathrm{X}$.

KTPB solids generally have been found to be fairly stable in a slurry at high $\mathrm{pH}$ and room temperature. Without the addition of a catalyst, heat, or irradiation by a radioactive source the solids should be stable for long periods of time. Tests No. 1, 2, 3, and $6-9$ all used simulated salt solutions spiked with NaTPB to prepare the saltstone samples for testing. None of these simulants contained sludge solids or any other source of metals that could be implicated in the catalytic decomposition of TPB. All of these tests, with the exception of No. 2 and 3, were conducted at $25^{\circ} \mathrm{C}$. The expectation would be, since the soluble TPB in the salt solution precipitates as KTPB when mixed with the saltstone dry blend chemicals and remains at high $\mathrm{pH}$ and $25^{\circ} \mathrm{C}$, that the decomposition of the TPB in the saltstone sample should be negligible. The small benzene generation rates observed in these tests may be attributable to TPB decomposition products present as impurities in the NaTPB reagents used to spike the salt solutions. However, Tests No. 6-9 measured the concentrations of the TPB decomposition products and found them to be very low. Another possible explanation for the very low decomposition rate in these saltstone samples would be that the saltstone dry blend chemicals contain a chemical component that can slowly react to decompose TPB or a potential catalyst to catalytically decompose TPB at a very slow rate. The testing in Section 2.5 where the saltstone dry blend chemicals were mixed with simulated salt solutions containing soluble TPB and its decomposition products seemed to indicate that although TPB was removed from solution by the saltstone dry blend chemicals, a significant increase in TPB decomposition products was not observed. However these tests were only conducted for 7 days and all of the solutions contained significant levels of TPB decomposition products that could mask small increases in the TPB decomposition products concentrations.

Besides Test No. 2, two other tests in Table 3.2 were conducted at elevated temperatures. In Test No. 3 the temperature reached $70{ }^{\circ} \mathrm{C}$ for six days during the test. Although the benzene generation rates remained low throughout the duration of that test, the individual rates 
determined for each measurement period follow the temperature profile of the test. The other test conducted at elevated temperature was Test No. 19 however, the salt solution for Test No. 19 contained only $3 \mathrm{~PB}$ and $2 \mathrm{~PB}$. In Test No. 19 , the temperature was held at $85^{\circ} \mathrm{C}$ for the first two days and then the saltstone sample was allowed to cool to room temperature. Again, the peak rate show in the table for Test No. 19 occurred during the period of high temperature. These results suggest the evolution of benzene from saltstone samples may show some temperature dependence as concluded in the 1986 study (see Section 2.2).

Tests No. 10 through 19 all contained measurable concentrations of TPB decomposition products and the highest average and peak benzene generation rates were found in some of these tests. The results of the benzene generation tests summarized in Table 3.2 suggest lower rates with saltstone prepared from solutions containing only TPB versus solutions containing measurable concentrations of TPB decomposition products. This same observation was made with respect to the results of the TCLP extractions in Section 3.1.

The current composition of Tank 48H contains 18,800 mg/L TPB ( 21,000 mg/L KTPB) and less than detectable concentrations of $3 \mathrm{~PB}, 2 \mathrm{~PB}$, and $1 \mathrm{~PB}{ }^{21}$ The Tank $48 \mathrm{H}$ material will be aggregated with non-TPB containing waste streams in Tank $50 \mathrm{H}$ prior to transfer to the Saltstone Processing Facility reducing the TPB concentration to approximately $5500 \mathrm{mg} / \mathrm{L}$ or less. Since the Tank $48 \mathrm{H}$ waste contains less than detectable concentrations $(<50 \mathrm{mg} / \mathrm{L})$ of TPB decomposition products, the benzene generation rate from saltstone prepared from this waste might be expected to model those for Tests No. 1 though 9 in Table 3.2 and show a fairly low rate. However, given the high uncertainty of the data reviewed from past tests, and the $\sim 2 \mathrm{X}$ higher concentration of TPB expected in the aggregated feed from Tank $48 \mathrm{H}$ than any salt solution tested to date, and the possibility of higher temperatures for extended period in the saltstone vault, the benzene generation rate would need to be confirmed with careful experimentation using actual waste samples from Tank $48 \mathrm{H}$.

To put the average benzene generation rates found in the review in some perspective, saltstone prepared from Tank $48 \mathrm{H}$ aggregated feed $(5500 \mathrm{mg} / \mathrm{L}$ TPB) would release benzene for $\sim 4000$ years at the rate of $0.1 \mu \mathrm{g} / \mathrm{hr} / \mathrm{L}$ and $\sim 3$ years at the rate of $140 \mu \mathrm{g} / \mathrm{hr} / \mathrm{L}$. These estimates assume complete decomposition of all the TPB present in the saltstone releasing four moles of benzene per mole of TPB. 
Table 3.2. Summary of Benzene Generation Rates for Saltstone Samples Prepared from Solutions Containing TPB and TPB Decomposition Products

\begin{tabular}{|l|l|c|c|c|c|c|c|c|c|c|c|}
\hline No. & $\begin{array}{l}\text { Salt } \\
\text { Solution }\end{array}$ & $\begin{array}{c}\text { Section } \\
\text { in } \\
\text { Report }\end{array}$ & $\begin{array}{c}\text { Curing } \\
\text { Temp }\end{array}$ & $\begin{array}{c}\text { Form of } \\
\text { TPB in } \\
\text { Salt } \\
\text { Solution }\end{array}$ & $\begin{array}{c}\text { Total } \\
\text { Duration } \\
\text { of Test } \\
(\text { days })\end{array}$ & $\begin{array}{c}\text { TPB } \\
\text { Conc. } \\
(\mathrm{mg} / \mathrm{L})\end{array}$ & $\begin{array}{c}3 \text { PB } \\
\text { Conc. } \\
(\mathrm{mg} / \mathrm{L})\end{array}$ & $\begin{array}{c}\text { 2PB } \\
\text { Conc. } \\
(\mathrm{mg} / \mathrm{L})\end{array}$ & $\begin{array}{c}\text { 1PB } \\
\text { Conc. } \\
(\mathrm{mg} / \mathrm{L})\end{array}$ & $\begin{array}{c}\text { Avg. } \\
\text { Benzene } \\
\text { Rate } \\
(\mu \mathrm{hr} / \mathrm{L})\end{array}$ & $\begin{array}{c}\text { Peak } \\
\text { Benzene } \\
\text { Rate } \\
(\mu \mathrm{g} / \mathrm{hr} / \mathrm{L})\end{array}$ \\
\hline 1 & Simulant & 2.2 & 25 & NaTPB & 10 & 750 & NA & NA & NA & $<3$ & 9 \\
\hline 2 & Simulant & 2.2 & 80 & NaTPB & 14 & 750 & NA & NA & NA & $70-140^{*}$ & $350^{*}$ \\
\hline 3 & Simulant & 2.2 & $70^{* *}$ & NaTPB & 55 & 750 & NA & NA & NA & 1 & 5 \\
\hline 4 & Tank 50H & 2.3 & 25 & KTPB & 55 & 295 & NA & NA & NA & 0.1 & 0.2 \\
\hline 5 & Tank 48H & 2.4 & 25 & NaTPB & 182 & 2000 & NA & NA & NA & 16 & 28 \\
\hline 6 & Simulant & 2.5 & 25 & NaTPB & 91 & 812 & $<10$ & $<10$ & $<20$ & $<0.1$ & $<0.1$ \\
\hline 7 & Simulant & 2.5 & 25 & NaTPB & 91 & 777 & $<10$ & $<10$ & $<20$ & $<0.1$ & 0.3 \\
\hline 8 & Simulant & 2.5 & 25 & NaTPB & 91 & 412 & $<10$ & $<10$ & $<20$ & $<0.1$ & 0.2 \\
\hline 9 & Simulant & 2.5 & 25 & NaTPB & 91 & 418 & $<10$ & $<10$ & $<20$ & $<0.1$ & 0.2 \\
\hline 10 & Simulant & 2.5 & 25 & NaTPB & 328 & 197 & 3168 & 322 & 180 & 41 & 67 \\
\hline 11 & Simulant & 2.5 & 25 & NaTPB & 328 & 109 & 1689 & 161 & 71 & 46 & 232 \\
\hline 12 & Simulant & 2.5 & 25 & NaTPB & 328 & $<10$ & $<10$ & 1770 & $<20$ & 15 & 104 \\
\hline 13 & Simulant & 2.5 & 25 & NaTPB & 328 & $<10$ & $<10$ & 1137 & $<20$ & 5 & 45 \\
\hline 14 & Simulant & 2.5 & 25 & NaTPB & 91 & $<10$ & $<10$ & $<10$ & 268 & 0.5 & 1.1 \\
\hline 15 & Simulant & 2.5 & 25 & NaTPB & 91 & $<10$ & $<10$ & $<10$ & 95 & 0.2 & 1.6 \\
\hline 16 & Simulant & 2.5 & 25 & NaTPB & 328 & 998 & 2944 & 2044 & 423 & 15 & 46 \\
\hline 17 & Simulant & 2.5 & 25 & NaTPB & 328 & 515 & 1591 & 787 & 204 & 85 & 272 \\
\hline 18 & Simulant & 2.6 & 25 & NaTPB & 138 & $<10$ & 318 & 20 & $<10$ & 10 & 17 \\
\hline 19 & Simulant & 2.6 & 85 & NaTPB & 138 & $<10$ & 318 & 20 & $<10$ & 16 & 60 \\
\hline
\end{tabular}

Note: $\mathrm{TPB}, 3 \mathrm{~PB}, 2 \mathrm{~PB}$, and $1 \mathrm{~PB}$ concentrations represent the concentrations present in the salt solution used to prepare the saltstone samples. NA - data not available * Data may not be reliable due to difficulties encountered with test, see Section 2.2 in report $* *$ Variable temperature used in test, maximum temperature shown 
WSRC-TR-2004-00383, REV. 0

\subsection{CONCLUSIONS FROM LITERATURE REVIEW}

\subsection{CONCLUSIONS ON TCLP PERFORMANCE}

The following conclusions can be drawn from the review of the literature with regard the effects of TPB on saltstone TCLP performance:

- $\quad$ TCLP results show very little benzene leached from saltstone samples prepared from samples containing up to $2000 \mathrm{mg} / \mathrm{L}$ (soluble) TPB with low concentrations of TPB decomposition products. Poorer TCLP performance was observed with saltstone samples prepared from solutions containing elevated concentrations of TPB decomposition products. The concentration of TPB decomposition products that begins to degrade TCLP performance cannot be quantified from the available data.

- $\quad$ The results of past tests suggest the initial form of the TPB in the salt solution (NaTPB or KTPB) does not appear to impact the TCLP performance of saltstone samples. A test conducted to investigate the effects of the saltstone dry blend materials with TPB containing solutions found that NaTPB was quickly removed from solution indicating an interaction with the potassium present in those materials. The TCLP results provide further evidence to suggest that soluble NaTPB in the initial salt solution precipitates or interacts with the potassium in the saltstone dry blend materials effectively producing (insoluble) KTPB in the saltstone.

- $\quad$ The current Tank 48H waste contains $\sim 18,800 \mathrm{mg} / \mathrm{L}$ TPB $(\sim 21,000 \mathrm{mg} / \mathrm{L}$ KTPB $)$ with less than detectable concentrations $(<50 \mathrm{mg} / \mathrm{L})$ of TPB decomposition products. The aggregated feed to the SPF produced from the Tank $48 \mathrm{H}$ material could have a TPB concentration of up to $5500 \mathrm{mg} / \mathrm{L}$, approximately $2 \mathrm{X}$ higher than any salt solution used for testing to date. The results of the reviewed tests suggest that saltstone prepared from the aggregated feed containing low concentrations of TPB decomposition products should perform well with respect to the TCLP. However, due to the $\sim 2 \mathrm{X}$ higher TPB concentration in the aggregated feed than any salt solution used for testing to date, TCLP testing of saltstone samples prepared using samples from the aggregated feed will be needed to verify saltstone prepared from this material will meet regulatory requirements.

\subsection{CONCLUSIONS ON BENZENE GENERATION}

The following conclusions can be drawn from the review of the literature with regard the effects of TPB on benzene generation from saltstone. However, the data from past studies of benzene generation from saltstone samples containing TPB and TPB decomposition products should be used with caution due to the large uncertainty associated with the data. The following conclusions on benzene generation from saltstone samples containing TPB and TPB decomposition products were drawn based on the available data and, therefore, contain the same level of uncertainty. 
- The average benzene generation rates, measured over the total duration of a test, span from $<0.1$ to $140 \mu \mathrm{g} / \mathrm{hr}$ per liter of saltstone in the reviewed studies. The peak rates, from individual measurement periods during the tests, range from $<0.1$ to $390 \mu \mathrm{g} / \mathrm{hr}$ per liter of saltstone. However, distinguishing what constitutes a statistically significant difference in rate proves difficult due to the high uncertainty present in the data.

- $\quad$ Results of past tests show low benzene generation rates with saltstone samples prepared with salt solutions containing up to $2000 \mathrm{mg} / \mathrm{L}$ TPB with low concentrations of TPB decomposition products. The highest average and peak benzene generation rates were found in saltstone samples prepared from salt solutions containing measurable concentrations of TPB decomposition products. Samples containing only 3PB showed the highest benzene generation rates while samples containing only $2 \mathrm{~PB}$ showed high rates for the first fourteen days and then decreased. These observations concur with the results of the TCLP extractions indicating the probability that decomposition of TPB proceeds at a slow rate in saltstone. The concentration of TPB decomposition products that results in higher benzene generation rates cannot be quantified from the available data.

- Results of past studies suggest the evolution of benzene from saltstone samples may show some temperature dependence with rates increasing with temperature. The change in benzene generation rate as a function of temperature cannot be quantified from the available data. The data also suggests that high peak rates may occur sooner when saltstone samples have been cured at higher temperature.

- $\quad$ Since the current Tank $48 \mathrm{H}$ waste contains less than detectable concentrations $(<50$ $\mathrm{mg} / \mathrm{L}$ ) of TPB decomposition products, the benzene generation rate from saltstone prepared from aggregated Tank $48 \mathrm{H}$ waste might be expected to be quite low based on the available data from past tests. However, given the high uncertainty of the reviewed data from past tests, the possibility of up to an $\sim 2 \mathrm{X}$ higher concentration of TPB in the SPF aggregated feed from Tank $48 \mathrm{H}$ than any salt solution tested to date, and the possibility of higher temperatures for an extended period in the saltstone vault, the benzene generation rate would need to be confirmed with careful experimentation using actual samples from aggregated Tank $48 \mathrm{H}$ waste. 


\subsection{RECOMMENDATIONS FOR FUTURE TESTING}

The following provides recommendations for further study to better define the potential issues with regard to incorporating TPB salts solutions into saltstone.

1) Conduct TCLP on saltstone samples prepared with the current Tank $48 \mathrm{H}$ material aggregated with DWPF recycle to confirm expectations that the material will meet TCLP requirements. Samples should be cured at the maximum temperatures or temperature profile expected in the saltstone vault in addition to tests at ambient temperature. Tests should use a procedure to minimize loss of benzene in sample preparation.

2) Determine the benzene generation rate that will cause problems in the SPF vaults with respect to regulatory issues and flammability limits. This rate will provide a basis for determining what detection limits are needed in the benzene generation tests with actual waste samples.

3) Conduct carefully controlled tests with saltstone samples prepared from current Tank $48 \mathrm{H}$ material for determination of benzene generation rates during saltstone curing. Accurate measurement of the small volumes of benzene evolved will require attention to detail in the experimental design. Some suggestions for the experimental design include;

- Careful calibration of test apparatus and analytical method with known benzene levels in the apparatus to determine trapping efficiency, efficiency of desorption of benzene from trap, and analytical uncertainty

- Conduct replicate experiments to allow determination of benzene measurement uncertainty

- Conduct control experiments using saltstone samples prepared from a Tank $48 \mathrm{H}$ simulant without TPB

- Larger sample size may increase detectability of the benzene evolved

- Longer measurement periods may increase detectability of the benzene evolved but will tend to even out spikes in the benzene generation rate

- Consider in situ measurement of benzene levels using GC to minimize possible problems with trapping efficiency and desorption of benzene from trap.

4) Conduct the benzene generation tests at the maximum temperatures or temperature profile expected in the saltstone vault in addition to tests at ambient temperature. Large and small sample volumes or the use of samples with different surface area may provide information on gas release mechanism. However, due to cracking and shrinkage, controlling the surface area of the samples may prove impractical.

5) Other tests to consider might include; benzene evolution from saltstone during mixing of the salt solution and dry blend chemicals, the effects of the layering of TPB containing saltstone, the effects of the gas generation on the integrity of saltstone and 
WSRC-TR-2004-00383, REV. 0

the saltstone vaults, and the stability of TPB in the presence of saltstone dry blend chemicals. 


\subsection{REFERENCES}

1. Dean, W. B., Technical Task Request: Saltstone Grout Formulation Testing for Tank 48H Disposition, SP-TTR-2004-00004, Rev. 0, February 27, 2004.

2. Cozzi, A. D. , Task Technical and QA Plan: Saltstone Grout Formulation Testing for Tank 48H Disposition, WSRC-RP-2004-00270, Rev. 0, April 12, 2004.

3. Fowler, R. C., Estimate of Total Tetraphneylborate in Tank 48, CBU-PED-200400013, April 6, 2004.

4. Maxwell, D., Barnes, M. J., Lambert, D. P., Tank 48H Disposition and Return to Service Research and Development Plan, CBU-SPT-2004-00144, Rev. 0, June 18, 2004.

5. Oblath, S. B., Benzene Evolution During Curing of Saltstone, DPST-86-645, September 2, 1986.

6. Poirier, M. R, TCLP Benzene Results and Preliminary Benzene Generation Rates from Saltstone Prepared with the January 1996 Tank 50H Sample, SRT-WHM-960013, February 22, 1996.

7. Poirier, M. R, Preliminary Benzene Evolution Rates During Saltstone Curing, SRTWHM-96-0014, February 28, 1996.

8. Poirier, M. R, Benzene Evolution Rates During Curing of Saltstone Prepared with Tank 50 Salt Solution, SRT-WHM-96-0029, April 26, 1996.

9. Langton, C. A, Saltstone TCLP Results Versus Curing Time and Initial Benzene Concentration, SRTC-WED-96-0163, February 27, 1996.

10. Poirier, M. R, TCLP Benzene Results from Saltstone Prepared with Tank $48 H$ Filtrate, SRT-WHM-96-0040, May 30, 1996.

11. Poirier, M. R, Benzene Evolution During Curing of Saltstone Prepared with Tank 48H Filtrate - Preliminary Data, SRT-WHM-96-0050, July 1, 1996.

12. Poirier, M. R, Benzene Evolution During Curing of Saltstone Prepared with Tank 48H Filtrate - Preliminary Data, SRT-WHM-96-0071, November 18, 1996.

13. Poirier, M. R, Benzene TCLP Results from Saltstone Prepared with NaTPB and Its Decomposition Products, WSRC-RP-97-0036, February 4, 1997. 
14. Poirier, M. R, Benzene Evolution Rates from Saltstone Prepared with NaTPB and Its Decomposition Products - Preliminary Data, WSRC-RP-97-0070, February 27, 1997.

15. Poirier, M. R, Impact of NaTPB and Its Decomposition Products on the Saltstone Process, WSRC-RP-97-0268, May 7, 1997.

16. Poirier, M. R, Benzene Generation from Phenylborate Decomposition in Saltstone, WSRC-TR-99-00154, May 21, 1999.

17. Monier Resources Inc., Material Safety Data Sheet for Flyash.

18. Radiological Performance Assessment for the Z-Area Saltstone Disposal Facility, WSRC-RP-92-1360, December 18, 1992.

19. Poirier, M. R, Benzene Evolution Rates from Saltstone Prepared with $2 X$ ITP Flowsheet Concentrations of Phenylborates and Heated to $85^{\circ} \mathrm{C}$, WSRC-TR-9900155 , May 21, 1999.

20. Poirier, M. R, Benzene TCLP Results from Saltstone Prepared with 2X ITP Flowsheet Concentrations of Phenylborates, WSRC-TR-99-00156, May 21, 1999.

21. Lambert, D. P., Peters, T. B., Stallings, M. E., Fink, S. D., Analysis of Tank 48H Samples HTF-E-03-73 (June 03, 2003) and HTF-E-03-127 (September 17, 2003), WSRC-TR-2003-00720, January 20, 2004. 